\section{ABSTRACT}

This article concerns embodied knowledge closely connected to dance experience. I position my research project primarily on three autobiographic dance narratives concerning my involvement with the dance genre known as contact improvisation (CI). In making the argument that practicing $\mathrm{CI}$ creates experience and knowledge that become embedded in the body, I attempt to give the dancing body an "audible voice", and apply theoretical concepts that are helpful in interpreting and elaborating my narratives.

Key words: Dance-based research, autoethnography, body archive, intercorporeality, contact improvisation

\section{SAMMENDRAG}

Hensikten med artikkelen og forskningsprosjektet den omhandler er å utvikle forskningsbasert kunnskap om erfaringer fra utøvelse av danseformen kontaktimprovisasjon. Til dette formål anvendes narrativer basert på erfaringer gjort som utøver av kontaktimprovisasjon. Narrativene får frem hvordan en dansers personlige refleksjoner utgjør en mulighet for å skape kroppsliggjort kunnskap og kunnskap om kroppslige minner. Jeg argumenterer for at det å gi den dansende kroppen en stemme utgjør en mulighet for å møte utordringen det byr på å utvikle kunnskap og begreper om og fra improvisert dans.

Nøkkelord: Dansebasert kunnskap, autoetnografi, mellomkroppslighet, kontaktimprovisasjon 


\section{PEER-REVIEWED ARTICLE}

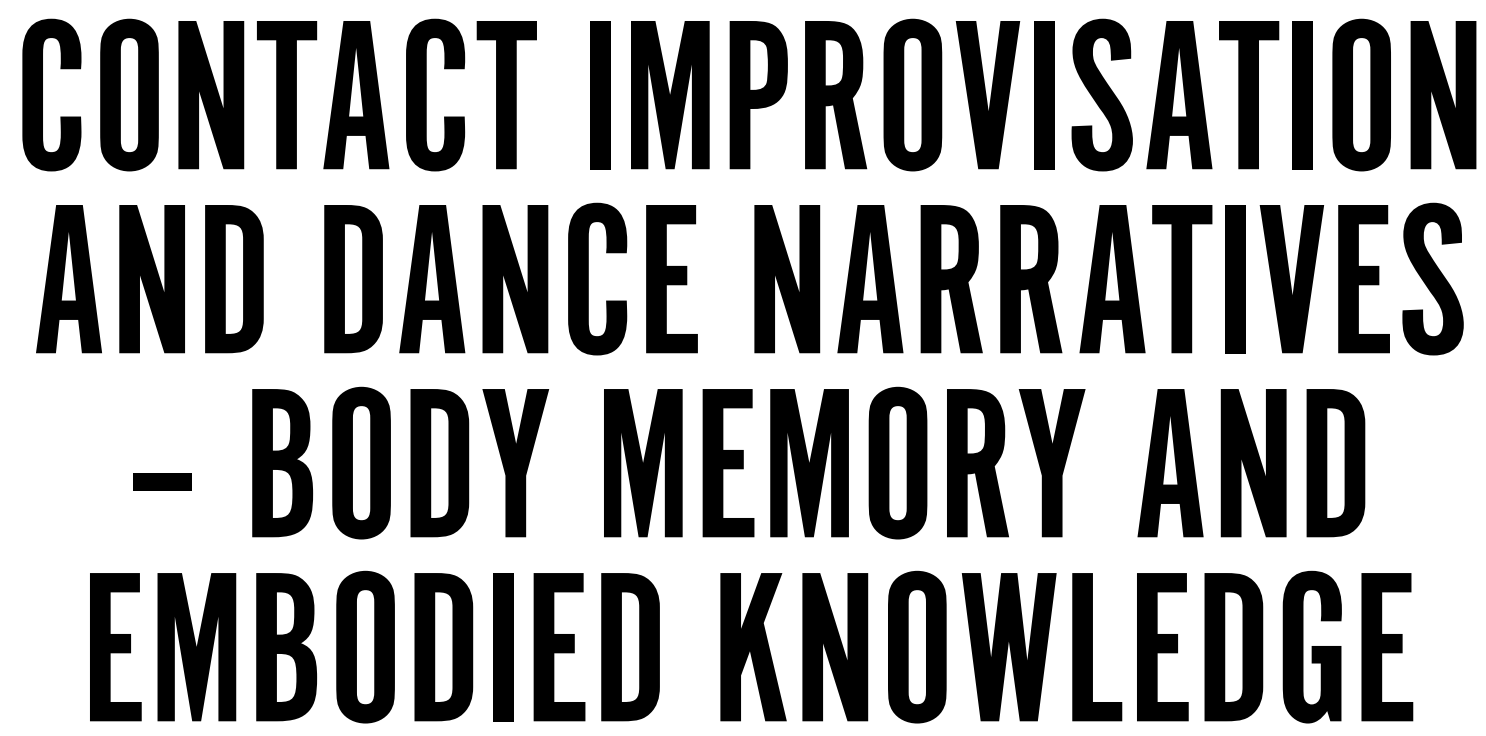

AUTHOR: Hilde Rustad* (PhD), Post Doctor, Norwegian School of Sport Sciences

My intention with this article is to analyse how narratives and verbalization of experiences with CI can show how a dancer's personal reflections can provide an opportunity for knowledge about dance as experience. By making connections between CI dance experience and bodily knowledge explicit, I intend to contribute to the field of dance research. I attempt to interpret the narratives through concepts and language that illuminate the connection and dependency of body as language and language as body. My research additionally concerns how CI experience situates the body and is situated within the body, as well as how this lived experience may be communicated through language that deepens insight and knowledge about moving and moving together.

I developed the following research question: What kind of embodied knowledge and meaning(s) can emerge through an analysis of autobiographical contact improvisation narratives, and bow may such analyses contribute to the research field of embodied learning in dance?

\footnotetext{
(C) 2019 Hilde Rustad. This is an Open Access article distributed under the terms of the Creative Commons Attribution 4.0 International License (http://creativecommons.org/licenses/by/4.0/).CITE

CITE THIS ARTICLE: Rustad, H. (2019). Contact improvisation and dance narratives - body memory and embodied knowledge. På Spissen forskning / Dance Articulated, Special Issue Bodily Learning 2019 (2), 27-45. DOI: HTTP://DX.DOI.ORG/10.18862/PS.2019.502.3

EDITOR FOR THIS ARTICLE: Gunn Engelsrud (PhD), Professor, Norwegian School of Sport Sciences. *CORRESPONDENCE TO: hilde.rustad@nih.no
} 


\section{Dance genre contact improvisation}

There are many definitions and descriptions of CI. Ray Chung, a renowned American contact dancer and teacher, describes it in this way:

Contact Improvisation is an open-ended exploration of the kinaesthetic possibilities of bodies moving through contact. Sometimes wild and athletic, sometimes quiet and meditative, it is a form open to all bodies and enquiring minds. (Chung, 2009)

To offer a fuller description, CI is a postmodern dance tradition; a specific kind of dance practice initiated by Steve Paxton in 1972, involving dancers in a certain type of tactile activity. CI is mostly, but not only, practiced as a duet. It is characterised by skin-to-skin touch, as well as by moving together with one or more other dancers who support each other's weight and improvise in a continuously changing situation. The closeness of these bodies in motion creates sensations of one's own skin, weight and smell - one's own and the other dancer's. When practicing CI, I simultaneously deal with/feel/sense/ perceive my own body in motion and my dance partners as we improvise in continuous bodily contact. CI dancers perceive each other in an exceptionally present manner: their area of shared, mutual touch may vary from fingertips to the entire surface of their bodies. One dancer may support or even carry from zero to 100 per cent of another's body-weight.

As a dancer, I have participated in CI workshops, festivals and group meetings around Europe. I have made notes, conducted interviews, compiled field notes and written dance narratives based on my participation. In this article, I use the terms "dancer" and "person practicing CI" interchangeably.

\section{Phenomenological approach}

To grasp and understand the moving and dancing body I have turned to the French philosopher Maurice Merleau-Ponty (1908-61). In his work, the concept of embodied is central and closely related to his thinking about habit. "To get used to a hat, a car or a stick", he asserts, (Merleau-Ponty, 2007/1945, p. 166) "is to be transplanted into them, or, conversely, to incorporate them into the bulk of our own body." (Merleau-Ponty, 2007/1945, p. 166) Elaborating further on this point, he writes:

If habit is neither a form of knowledge nor an involuntary action, what then is it? It is knowledge in the hands, which is forthcoming only when bodily effort is made, and cannot be formulated in detachment from that effort. (Merleau-Ponty, 2007/1945, p. 166)

Based on this perspective, CI experience is knowledge in the body; that is, embodied knowledge activated in the actual practice of CI.

Merleau-Ponty's concept of habit further relates to body memory, which Thomas Fuchs (2016a) defines in this way:

$[\mathrm{T}]$ he entirety of established practices and skills that are available through the medium of 
the lived body without the need to remember earlier situations. Habits formed through repetition and practice are activated of their own accord; well-rehearsed sequences of movement have been incorporated, thus becoming a bodily capacity. (Fuchs, 2016a, p. 221)

Fuchs, like Merleau-Ponty, compares this to using instruments like a bicycle or a typewriter:

$[\mathrm{T}]$ his bodily memory ${ }^{1}[\ldots]$ does not re-present or "presentify" the past, it rather reenacts it in the ongoing conduct of life. In the last analysis, all capacities during one's life point to a primordial capacity of the embodied subject, to a basic "I can". (Husserl, 1952, p. 253, in Fuchs 2016a, p. 221)

A related concept is participatory sense-making, which Fuchs and Hanne De Jaegher (2009) define as "the process of generating and transforming meaning in the interplay between interacting individuals and the interaction process itself" (Fuchs \& De Jaegher, 2009, p. 466). Fuchs and De Jaegher elaborate on the phenomenological aspect of this process by introducing the notion of mutual incorporation, which they describe as "a process in which the lived bodies of both participants extend and form a common intercorporality" (Fuchs \& De Jaegher, 2009, p. 465, my emphasis). They also introduce intersubjectivity to describe a process of embodied interaction that generates common meaning (Fuchs \& De Jaegher, 2009, p.465-466). In order to follow these perspectives, I turned to autoethnography to create material that could be further analysed from the conceptual frame of phenomenology

\section{Autoethnography}

In autoethnography, Jacquelyn Allen-Collinson (2012, p. 4) suggests that the term 'autoethnography' incorporates "auto" (self). Here, the term refers to my experience and myself (as the author); "ethno", which Allen-Collinson (2012) observes, "nowadays more usually applies to a socio-cultural group" (p. 5) - in this article, to the European contact improvisation community (Rustad, 2017, p.71); and "graphy," here refers to the act of writing and processing.

I use the term autoethnography to share the experience of the writer - in this case a CI dancer, teacher and researcher - and thereby encourage appreciation and understanding of lived CI experience, which may resonate with experiences that readers of this article have had in other environments. As Max van Manen (1990, p. 54) has observed, "in drawing up personal descriptions of lived experiences, the phenomenologist knows that one's own experiences are also the possible experiences of others".

According to Heewong Chang (2008, p. 48), "autoethnography should be ethnographic in its methodological orientation, cultural in its interpretive orientation and autobiographic in its content orientation". She notes that although the degree to which an autoethnographer emphasizes each of these three axes will vary, the work combines cultural analyses and interpretation with narratives. In this article, I conform 
to that description: I use autobiographic narratives as objects of further reflection, analysis and interpretation in a wider socio-cultural context and theoretical framework. I base the article on my own narratives that have evolved in context with others and comprise some ethical reflections.

\section{Ethics}

As already stated I focus on embodied interaction in practicing CI as both a personal and relational experience. Taking an autoethnographic approach has enabled me to (re)examine my own texts and experiences, and not the explicit experiences of others. As I am doing research in a field in which I am also a practitioner, I avoid possible confrontations and conflicts with other practitioners, which might arise if I had applied other methods and researched other dancers' experiences. Trish Van Katwik \& Yukari Seko (2017, p. 2) observe that autoethnography is a way of "objecting to other research practices that potentially diminish the life experiences being studied.", and rather than diminishing life experiences autoethnography opens for expansion.

Leon Anderson (2006, p.384) emphasizes that "autoethnography demands enhanced textual visibility of the researcher's self. Such visibility demonstrates the researcher's personal engagement in the social world under study." He adds, "[a]utoethnographers should expect to be involved in the construction of meaning and values in the social worlds they investigate" (p. 384).

There are different ways of applying autoethnography. My approach is both evocative and analytical (Anderson, 2006; Ellis \& Bochner, 2006). I use "layered accounts", as described by Carolyn Ellis, Tony E. Adams \& Arthur P. Bochner (2011, p.6), focusing on my own experience along with data, abstract analysis and relevant literature. With this approach, collection and analysis may take place simultaneously (Charmaz, 1983, p.110, in Ellis et al. 2011, p. 6), and frame existing research as a "source of questions and comparisons," rather than a "measure of truth." Layered accounts may use a variety of representational forms as research material, including poetry, essays, personal reflections, diaries, journals and (as I do) narratives to invite readers to enter into the emergent experience of doing and writing up research. In addition, work using this approach "can be inspired by otherwise common qualitative research methods such as participant observation, reflective writing, or interviews" (Richie \& Brooke, 2018, p. 2). In this project, I have utilized writing, dancing, observing, reflecting and reading.

\section{Research material}

I have chosen three autobiographic narratives that I consider as explorative attempts in "writing dance," inspired by phenomenological description. The intention is to catch aspects of CI dancing and to "dwell in the flux of lived experience" (Ellis \& Bochner, 2006, p. 431). In line with van Manen (1990) who claims that,"the meaning of lived experience is usually hidden or veiled" (p. 27) I aim at elucidating lived CI experience.

The situations from dancing described in the narratives took place in different countries, on different occasions, and in different years. Narrative I, "Shoulder blade exchange" (Rustad 2006), describes the very end of a CI duet. Narrative II, "Slow and sleepy 
dancing," is a discussion of the first part of a CI duet at a 2010 contact festival, written shortly after the festival ended. Narrative III, "Wild jam dancing," is from a CI trio at a 2018 contact jam. I consciously observed and made notes of my observations before, during and after this session; the first draft of Narrative III is part of these field notes.

In sum, the research material consists of dance narratives written over a period of approximately 14 years. I hope they catch and convey some of the sensations and experiences I had while dancing. I also draw on my field notes. Although each of the three dances described was deeply meaningful to me, the narratives are not spectacular, scandalous, highly emotional or revealing. Their ordinariness is consistent with Paxton's early characterization of $\mathrm{CI}$ as "an on-going phenomenon that is available occasionally for observation. It is a display but not of virtuosity. Rather it's a showing of how communication changes" (Paxton 1975, p. 30, in Yohalem 2018, p.51), which I will continue to show in the following.

\section{Analysis and interpretation}

The narratives correspond to actual contact improvisations in which I participated. Following Chang (2008, p.146), these experiences and events "are described as 'accurately' as possible", and "analysis and interpretation are intimately intertwined". I understand language as dependent on intercorporeality, and thereby connected to "a sphere of reciprocal bodily understanding and interaction, from which words first draw their references and meanings"("intercorporéitê": Merleau-Ponty, 1960, in Fuchs, 2016b, p.108). Chang stresses the importance and necessity of what she calls a "custom tailored" approach in autoethnographic analysis (2008, p. 130), and my analysis draws on embodied knowledge that I have acquired through my experiences with the research material, as well as with the ways CI dancers move with each other. In analysing the narratives, I followed Chang's recommendation to draw on insight, intuition and impression to determine what resonated with my embodied experience, and identified three recurring themes: "Mutuality in contact improvisation", "Kinaesthetic sensing and meaning-making in contact improvisation", and "Embodied memories of past contact improvisations".

I have used italics to emphasize the most evocative passages in each narrative to assist readers in getting deeper into the situation described so that they can better "experience the experience" (Ellis \& Bochner, 2011, p. 4). After each narrative, I offer my reflections on the highlighted phrases. After having presented the narratives with reflections, I discuss each theme separately. I open my discussion of each theme with a list of sentence excerpts that pertain to it in order to make the connection between the narratives and the themes transparent. The excerpts are drawn from all three narratives, and viewed together they reveal themes that suggest multiple layers of meaning.

\section{Dance narratives and reflections}

Narrative I: Shoulder blade exchange

We end up standing back-to-back, leaning into each other's shoulder blades. Our dance has been playful, intense, and all encompassing. Warm togetherness passes 
between us. Weight, effort, energy, movement, which in the moments just past constituted the dance, bave ended in this shoulder blade sharing that resonates in my body and reminds me of a previous dance that I danced at a different time in a different place. This last dance integrates itself into my lived body and the shared stories of our bodies, as treasures of lived experience. Our dance lasted long enough to make us able to read each other's movement intentions before the movement itself unfolded. Body borders are changed. We are like Siamese twins until our bodies finally separate. Barely visibly. Carefully. Only the imprints remain. (Rustad, 2006, p.66, my translation).

This narrative describes and refers to a period in a duet when, after being in motion for a long time, our bodies have reached a stillness, but one in which the duet continues in silent sharing of bodily sensations, through breathing and touch. My dance partner and I are still together. The text highlights these moments in which the dance lingers on before we separate and the activity of our bodies moves us apart. CI is not limited to movement, and CI dancers sometimes hardly move for long periods. In this case, the movement phase went on for an extended period before evolving into a stillness in which the dance is on the verge of a slow ending and transformation into a deep and "ineffable" meaning.

The shoulder blade sharing is important not only as the conclusion of the dance, but also due to its representation of the entire dance as it unfolded. The evocative passages in the narrative convey the sharing of warmth, togetherness and information, overtly and intuitively communicated. This exchange indicates that both dancers feel and sense the silent communication passing between bodies. The movements that happen within one dance can arouse body memory and evoke conscious memories of earlier dances, which remain and change in new situations.

\section{Narrative II: Slow and sleepy dancing}

She sits close to the edge of the stage, and I, just finished with a dance, stand nearby, leaning on the stage, resting. I walk towards her and I stretch my hand towards ber; she takes my hand and stands up. We walk together towards the centre of the space. Music is being played: some kind of quiet piano music, which plays a part in setting the structure and tempo of our dance. Soon, we calmly descend to the floor and dance extremely slowly; we mostly stay down on the floor. We are rolling, rolling and rolling.

As a slow mass in continuous movement. As if we were glaciers in infinite movement. A rolling glacier quality, our hips somebow perfectly matching each other in size and relation; I can follow/pay attention to myself as a mass in movement. Having this feeling of being bones and liquid, and without edges. Me, a container in which mass is in motion - and gravity and weight-our dance movements lead onwards. A floatingunrbytbmic continuity in which we move up "on heights" and roll down into "valleys", sliding on each other's bodies to the floor, in forward movements while I am simultaneously slowly turning around on my own axis. We roll along and over the longer side of each other's bodies, as well as diagonally, with our legs intertwined in strange ways. This works only when the dancing persons have years of practice in their bodies. A state of cornerlessness, with floating skeletons, in the way that bones are no obstacle to bow the dance has its way of . 
continuously moving along. Our way of moving transcends practiced patterns and is now in its becoming. Infinitely.

Long rolling dancing, where we additionally explore how one may move differently. Somehow even, floating, unrbythmic, rbytbm. Juicy. Full of liquid. Weight. Masscontinuously moving. Satisfying. I get slow and sleepy thinking about it - recalling this dance. (Fieldnotes from 2010)

When reading this narrative eight years after I wrote it, the "slow motion-ness" of this particular situation comes to my body memory. It is as if my body still remembers the quality of movement and the atmosphere of this particular dance. In retrospect, I find the way I described this actual CI duet using words interesting; by doing so, I make the dance live on. The first-person narrative, present tense, along with in medias res in the first part, gave me a feeling and potential to "co-live" the dance experience eight years later. The text has a poetic quality, in the sense that I have used metaphors of nature such as heights and valleys, portraying rolling bodies in motion as landscapes in which dancers play together. In this way, the CI experience constitutes the place in which the dance unfolds. CI unfolds in, through and on the bodies.

\section{Narrative III: Wild jam dancing}

Before I "knew", what I was doing or thinking I threw myself into the dance with two men I did not know and had never previously danced with. To me, they seemed to be engaged in a somewhat wild, lush duet, which in no way went "by the book." Neither of them was careful. They both seemed quite the opposite. In that very moment, my body recognized and associated what was going on with similar behavior I had experienced in the past. It could be me dancing this way.

The reckless action - that it was possible to move in this way - shows experience, recognition and attraction, as well as trust. The way they were moving was irresistible to me, and as a response my body/I reacted instantly - and the next instant I plunged in. What had been a duet now became a trio. I believe this happened in the following way: I, already tired, had no resistance - I sensed [...] the dancers, their presence and energy and felt attracted, had no hesitation, went for it, and was instantly in. Instantly accepted.

In this trio, I was moving in a way I had not moved for a very long time. I was rolling around on top of people who were standing upright and moving, providing space/ground for me to move on - rolling around their necks and shoulders. I could sense my body sort of flicking itself inside out and about in a way that I truly enjoyed - but that also introduced a bigher degree of difficulty than I remember baving encountered in a long time. Without fear - I could sense bow my body memory was catching up - the prior experience cleansed and renewed. Bodily knowledge instantly activated. Responding to the demands of the situation. (Narrative from 2018) 
Narrative III depicts a short dance. It describes this dance in present time, along with prior movement experience. Unlike Narrative I, which is about the conclusion of a duet, Narrative III begins with me entering a duet that is already in progress. The narrative also refers to how embodied memory is (re)activated.

Following Chang (2008), who writes that in autoethnography data, becoming and interpretation may occur simultaneously, I wrote, rewrote, edited and added on to Narrative III while writing this article. The first draft of Narrative III went this way:

My dancing culminated when I flung myself into a duet that bad already been going on for a long time. I bad to swing myself in the higher spheres and be turned inside out in all directions. Awesome! As one is strongly attracted and without hesitation throws oneself into the dancing. Everything becomes right. It just tunes in and "boils." (Field notes 2018, my translation)

The feeling that everything becomes right is central here. As such, the narrative illuminates the wishes for being absorbed in the dance and trusting the body. When comparing the two versions, they differ regarding reflection about my own way of participating. In the first situation, I was unaware that I took gender and my own attraction for granted. In the current narrative I include information about the other dancers (their gender), and provide details concerning the movement explorations during the dancing. To re-read the original draft reminded me of the explorative movements and made me feel that I was brought "back into the dancing". Going "back" to the situation and adding to it indicate body memory as something that one continuously creates and renews.

Whereas the dance referred to in Narrative II proceeded at a slow pace that made it possible to follow the body-mass movement moment by moment, the dancers in Narrative III had much less control - if any. The chaotic speediness excludes conscious moment-by-moment sensations. It activated body memory, reproduced traces of previous dances, and both required and generated embodied knowledge. The dance involved physical risk-taking; it was trustful and not experienced as dangerous, and shows how embodied knowledge emerged in response to the bodily effort (MerleauPonty, 2007/1945, p 166), and the dancers were present. I experienced this dance as a situation in which the interactions among the three of us were generating and instantly transforming meaning. This kind of meaning relates to the trust inherent in the way CI dancers respond to the bodily knowledge they recognize in other dancers through sensing how they move. In the dance situations, we were all actively involved in participatory sense-making; embodied knowledge was realized through body memory as habitual action based on earlier experiences, as well as through volitional acts (Fuchs, 2016a, p. 217-218). 
Theme 1: Mutuality in contact improvisation

Sentence-excerpts:

From Narrative I: Warm togetherness passes between us/shoulder blade sharing/shared stories/to read each other's movement intention before the movement itself unfolded/

From Narrative II: we roll not across, but along.../ work only when the persons dancing bave years of practice within their bodies/

From Narrative III: providing space/ground for me to move on/bodily knowledge instantly activated. Answering to what was demanded/

In CI, while moving very slowly, and sometimes almost not at all, I am able simultaneously to sense myself kinaestehically in movement as well as how my dance partner is moving; we are both continuously attentive to what is going on between us and to the changing forms of our bodies. I perceive more sensory information in CI duet dancing than when I dance alone, and instantly perceive the information that I continuously process and act on. The sentence-excerpt "to read each other's movement intention before the movement itself unfolded" is about attentive listening through the touching body-parts, and the body-part(s) touching will be continuously changing, as the bodies are moving. I experience the "reading" a lot of the time simultaneously as the movement unfolds, rather than before. In Narrative I, the dancers pay attention, notice and respond interactionally to the slightest shift in the other's body. What goes on resonates inter-bodily, and has to do with dynamic mutual communication (Fuchs and Koch, 2014, p. 5).

We, the dancers in narrative II , were able to roll together the way we did - enmeshed in each other's bodies without either knowing or worrying about what was to come next - because through experience we had embodied the "I cans" that enabled us to move precisely in this way. Although we had never moved in this way together before, through our bodily sensitivity we intuitively understood where we were heading. Due to the socialization of CI dancers' bodies, dancers who have never met before have the capacity to meet and connect in accordance with the tradition, and they know that their partners have similar experience. Merleau-Ponty's concept babit actualizes the mutuality and embodied habits that both dancers possess and are able to activate in the actual dance situation. The "I cans" in question in Narrative II include rolling skills, which, in order to soften the meeting between body and floor, involve fascia and flesh rather than bones.

Whereas Merleau-Ponty and Fuchs both explain "I can" in terms of using objects, the situation of dancing CI means that there is no predictable object, like a typewriter or bicycle, but a fully fleshed independently moving body-subject each dancer has to relate to, as well as the floor, and both function as affordances for dance improvising.

Intersubjective experience: lifting and being lifted 
In the dance of Narrative III, there was a lot of lifting. If asked to write about such experience, dancers may offer substantially different versions. Whilst one experienced being lifted, the other experienced lifting. Thus, such intertwined experiences are far from identical. This indicates the unequal relationship between the subjective experience and the intersubjective dance situation, as well as the dynamic nature of the $\mathrm{CI}$ experience as simultaneously individual and shared. However, it is my experience that when a person is lifting another, both the lifter and the lifted acquire bodily knowledge of both situations. This perspective relates to phenomenology, in particular to van Manen's (2014, p. 390) suggestion that even though our individual experiences are never precisely the same, phenomenological meaning is plural in its singularity.

\section{Attentive body-listening}

As I have shown, subjective listening and sensing is central in CI. However, I link the excerpt "to read each other's movement intention before the movement itself unfolded" to intersubjectivity. Fuchs and De Jaegher (2009, p. 469) discuss "social understanding as an interactional affair," relying heavily on embodiment in a rich sense of the word, i.e. on dynamic and embedded whole-body actions (such as occur in CI), in which "intentions are expressed in action and can be perceptible to others". In addition, Narrative I makes it clear that the dancers are familiar with CI as a social context; they know what they expect and what others expect from them in terms of meeting and dancing non-verbally.

Theme 1, "Mutuality in contact improvisation" further relates to intersubjectivity as openness towards others. Listening is essential in verbal communication and dialogue; it is also in CI, where listening through the body is part of the practice and strongly emphasized. Dancers are encouraged to be as present as possible moment-to-moment in continuous body-communication. I regard this as a powerful example of Fuchs and Koch's (2014, p. 6) observation that "the other's body extends onto my own, and my own extends onto the other". Contact dancers practise listening on several levels: to their own body, to their partners' bodies, and to what goes on between them. The mutual listening is a form of "embodied interaffectivity", of social interaction and shared moments (Fuchs and Koch, 2014, p.2). Contact dancers listen actively to let the improvisation emerge and to go along to wherever it takes them.

The dance of Narrative I brings the following quote to my mind: "Although it is a silent exchange, I could perceive speech streaming between them" (Sarah, 2004, p. 37). ${ }^{2}$ Such deeply felt bodily dialogue has to do with how both dancers in a CI duet are simultaneously perceivers and perceived. At some point the dancers' intentions meet and become one; they collaborate and share an embodied mutual understanding of what is about to happen and how to get there.

2. Sarah is one of the authors of Underscore practice; Vellexon 2004 which is a private publication in which a group of $15 \mathrm{Cl}$ dancers, myself included, wrote about $\mathrm{Cl}$ experiences after having spent a week of dancing together. 
Theme 2: Kinaesthetic sensing and meaning-making in contact improvisation

\author{
Sentence-excerpts: \\ From Narrative I: The body borders are changed
}

From Narrative II: extremely calmly, as if we were glaciers in infinite movement. Glacier rolling quality/bipsperfectly match/pay attention to myself as physical mass in movement/being bones and liquid and without edges/we move up on beights and roll down into valleys/slowly turning around my own axis/cornerlessness, with floating skeletons/bones are no obstacle/

From Narrative III: sense my body sort of flicking itself inside out and about/

The excerpts cited above connect with different kinaesthetic sensations, of sensing oneself while moving. They communicate some of how I sense my own body, as well as our bodies together, and of how these sensations give associations of bodies as being landscapes of nature. "Sensation is the language of the body," Nancy Stark Smith $^{3}$ once said in a workshop I attended. She was indicating that sensation is close to communication, or equivalent to it. However, communication is usually associated with duration and dialogue, whereas in CI, bodily interaction based on kinaesthetic sensing has a different kind of immediacy. Bringing bodies together in intercorporeal CI activity can generate interbody resonance and spontaneous actions.

The extracted words and metaphors such as "liquid", "without edges" and "cornerlessness" indicate desirable states. Opposite terms might include "being solid", "having edges," and "having corners." When two or more bodies engage in CI, roundness and a sense of body liquidity enable the participants to experience their dancing in a positive way and facilitate improvisation. The excerpts above hint also at softness, which indicates the body borders have become more permeable, and, as such, more open to communication through the body.

The slow moment-by-moment mutual attention in the Narrative II dance orients the dancers towards the experience of moving, rather than towards its physical expression. Nita Little has suggested that this may serve to clarify details of the experience (Little, 2014, p. 248). It may also give the dancers a sense of extended time. In addition, moving slowly may enhance the "sensual haptic quality" (van Katwyk \& Seko, 2017, p. 9) experienced in CI's more meditative modes.

\title{
Kinaesthetic socialization
}

As the dance narratives indicate, $\mathrm{CI}$ has a repetitive structure. In addition, as noted earlier, experienced dancers participate in numerous dances. However, $\mathrm{CI}$ is a context in which people meet and socialize as well as dance. In addition to such "normal" socialization, the participants engage in kinaesthetic socialization. Derek McCormack writes that the bodies of dancers in general have "developed the capacity to be affected

3. Nancy Stark Smith is an American contact improvisation dancer and teacher, who has been part of developing $\mathrm{Cl}$ from its very beginning until today. She is a central figure in the international $\mathrm{Cl}$ community through her dancing, teaching, editorial work and writing. 
by other bodies" (McCormack, 2013, p.74). I would argue that this is even truer in CI: because it is based on dancers' bodies touching and responding to each other, kinaesthetic socialisation'4 is inevitable, and often paves the way for long-lasting, dancingtogether-based relationships. CI thus extends the common concept of "social". CI is a non-verbal, whole-body, interactive dance improvisation action, and a kinaestheticsocial activity that offers the possibility of communicating and socializing on a deep, meaningful, non-verbal level.

As a participatory and inclusive dance practice drawing on what Van Katwyk \& Seko (2017, p. 8) have termed multiple ways of knowing, CI produces embodied knowledge that is community-based, as well as community-generative: CI-dancers get to know each other through kinaesthetic socialization.

\section{Meaning-making in CI}

One may ask what kind of participatory sense-making CI involves, and I have previously stated that $\mathrm{CI}$ is a situation in which participatory sense-making takes place, which means it is about "the process of generating and transforming meaning in the interplay between interacting individuals and the interaction process itself "(Fuchs \& De Jaegher, 2009, p. 466). The interaction process at stake is CI, in which the dancers can be understood as "fully 'switched on' proprioceptively, kinaesthetically, visually, auditorially and tacitly" (phrasing borrowed from Stuart, 2012, p. 170), and where meaning is made within all of these sense-areas.

Practicing the form of $\mathrm{CI}$ is a co-lived experience and a constantly shifting process in which the dancers actively take the other dancers' weight, actions, and changing shape, as if "into the bulk of their own body" (Merleau-Ponty, 2007/1945, p. 166). The dancers inhabit each other's personal and intimate space, reading and relating to body shapes and movement activity as the dance unfolds. Meaning-making takes place individually, and/or together, as well as through bodily dialogue and in between, and may relate to kinaesthetic or common socialization, body memory and habit. In CI, dancing may be experienced pre-reflectively, as ineffably embodied movement-meaning, and as such, inseparable from the dance-situation.

\section{Theme 3: Embodied memories of past contact improvisations}

Sentence-excerpts:

From Narrative I: Resonates in my body with another dance/the imprints remain/

From Narrative II: years of practice in their bodies/transcends practiced patterns/

From Narrative III: similar behavior in my past/I bave participated in similar dances before/based on experience/I performed movements I bad not attempted for a very long time/ body memory was catching up - prior experience cleansed and renewed/bodily knowledge

4. McCormack, in Refrains for moving bodies (2013, p. 74) writes about "kinaesthetic socialization", referring to the anthropologist Gregory Bateson's fieldwork in Bali. 


\section{instantly activated}

Individuals who practice CI for many years dance hundreds of dances or more, and conscious memories of numerous dances that $I$ have experienced now seem inaccessible to me. However difficult they may be to remember, I understand all my dances as part of me and incorporated in my body memory.

What I experienced as wild dancing in Narrative III and how I responded to it is closely related to Merleau-Ponty's habit, and may be even better explained through the French philosopher Henry Bergson's (1859-1941) concept babit-memory, in which "perceptions are prolonged into movements that modify the body organically, creating within it new dispositions towards action" (Bergson, 1988, p.81-2, in Burton, 2011, p. 27). This means that the body assimilates experiences and efforts, and can recover them "in the form and character with which its movements take place." Thus, like habit-memory, body memory imbues the present with "its own past by an intimate osmotic intertwining with it" (Casey, 1987, p. 178, in Burton, 2011, p. 27).

CI is an improvisation-practice, which means that body memory is gained not, as Fuchs (2016a, p. 221) writes, merely through "well-rehearsed sequences of movement", but mostly through unforeseen ways of moving. Thus, CI-dancers perform not only previously practiced movements, but - as habit-memory indicates - they transcend practiced patterns and move in new ways. This is possible because of the dispositions layered in their bodies through past dancing. This being said, it is important to point out that experienced dancers are often able to identify quite precisely what is going on - as it is going on - and anticipate what is to come next.

In the wild-dance of Narrative III, we were going for disorientation. I enjoyed not knowing, being upside down and around, and letting go of control. In the situation, I trusted the other dancers, their bodies and my own embodied knowledge. This again relates to babit, and as Merleau-Ponty (2007/1945, p. 165) writes, "it is the body which catches and comprehends movement. The acquisition of a habit is indeed the grasping of a significance, but it is the motor grasping of a motor significance". CI dancers are able to orient themselves in space from upside down positions in fast movement while sensing others and still staying centered. This is possible due to embodied knowledge, body habits and how the body has learned from previous experience and incorporated the new knowledge "into its world" (Merleau-Ponty, 2007/1945, p.160), and also how the vestibular apparatus in the inner ear functions in conjunction with the attitude of the body (Stuart, 2012, p. 170). The body has its own way of balancing and orientating even in situations of disorientation.

\section{The transformative power of dancing}

Writing autobiographical dance narratives is a way of exploring oneself and reflecting on the question, "Who am I?", which is both subjective and intersubjective, but also ontological and performative. Embodied dance experience has transformative power; the experience of movement has the potential to change the person moving in the 
movement-moment, as well as how the person will move in future dances. The dancing itself offers the possibility for change, and of becoming a different self. Practicing CI for years may transform dancers in several ways as they incorporate new experience that becomes part of their body memory. Edward Casey (1987, p. 163, in Burton 2011, p. 28) points out how body memory is not "just something we merely have, it is something that we are; that constitutes us as we exist humanly in the world." In other words, what we call 'the person'... is rooted ultimately in body memory" (Casey, 1987, p. 176, in Burton, 2011, 28). From this perspective, all of my dancing is part of my body memory, and thus part of my identity.

\section{Immediacy and interaffordance}

The mutuality of the intercorporeal dance-situation in which two or more dancers participate is a form of interaffordance: that is, each CI moment presents infinite choice. One dancer's actions may open up affordances for her or him, but these actions may constrain the affordances available to the other dancer(s). Whenever one dancer makes a choice, the others have to respond. However, the dancers involved may experience that they make choices together, or that the improvisation itself presents both choices and solutions. Thus, the dancers can simply be with the CI-situation and stay attentive and responsive.

CI is a form of interactive movement practice that may provide "... a corporeal memory that extends from the cellular to the social" (Burton, 2011, p. 30). I understand the concept 'corporeal memory' as being close to 'body memory'; as such, it offers possibilities in the present moment. The excerpt "bodily knowledge instantly activated" provides an example of how dancers access and activate embodied knowledge in action and interaction. CI dancing is lived and perceived by the participants simultaneously, and moving fast in CI might be experienced as if "... the signals and reactions involved proceed far too quickly to become conscious as such" (Fuchs \& Koch, 2016, p. 6).

This relates to Don Beith's (2018, p. 16) argument that Merleau-Ponty "develops a generative conception of the past as a soil of possibility beyond the terms of conscious acts, and even beyond those of the living body's activities...”.

\section{Summary and conclusion}

I have used narratives written with reference to autoethnography as a method in answering my research question, "What kind of embodied knowledge and meaning(s) can emerge through an analysis of autobiographical contact improvisation narratives, and how may such analyses contribute to the research field of embodied learning in dance?" I have identified themes concerning mutuality, kinaesthetic sensing and meaning making, and embodied memory. The experience of dancing in different situations is familiar to the experienced CI dancer. My argument is that familiarity in situations of CI opens for sensations and a variety of experiences among dancers. Together, the dancers' bodies, experiences and actions shape their dance both based on earlier experience and moment to moment unfolding in dancing. The dancing sensing bodies in dialogue and reciprocity with each other play an integral role in $\mathrm{CI}$ as a full- 
bodied, pre-verbal, sense-making dance practice. The themes further suggest the need for a broad understanding of body memory that encompasses embodied knowledge gained through shared dance experience.

The article makes transparent how $\mathrm{CI}$ dancing retrieves body memory as knowledge and incorporates it in action. This process shows how lived CI experience, understood through the theoretical concept of habit as bodily knowledge relates to the concept of past as the "soil of possibility" for future actions, as well as to phenomenology's "I can" (Merleau-Ponty, 2007/1945, p. 159).

In this article, I regard CI dance narratives as a meaningful way of connecting dance and language, embodied knowledge and body memory. Moving and writing give authorship of both dance and narrative as situated in the dancer's body, just as the dancers' bodies situate the contact improvisation by constituting a substantial portion of the place in which the dance unfolds.

CI dancers experience mutual incorporation and form intercorporalities. In CI, interacting dancers generate and transform meaning through "participatory sensemaking”. How and what they sense while moving, and the continuous stream of information they exchange influence - and even define and direct - their continuous stream of movement action and choices. The meaningfulness in CI dancing is embedded in intercorporeality, the closeness achieved through responsive interactions between dancers and the process of being and acting together in improvisation based on mutual kinaesthetic sensation.

The narratives give "afterlife" to specific contact improvisations. Writing opens for further connection with the experience of actual dances, CI experiences continue to live and can be shared with others. CI narratives counter the ephemeral quality of improvised dances, deepen the author's understanding and appreciation, and open up the possibility of sharing the dances with readers who did not witness them. The meaningfulness, specificity and importance of these dances become visible and may deepen through re-examination. In sum, writing CI dance narratives validates CI dancing and dances, as well as the dance improviser.

I have tried to show how dance narratives, when analysed and given voice, strengthen the CI dancer's bodily knowledge and illuminate knowledge that is created in CI as an explorative dance form. In order to illuminate the specific embodied knowledge, I have borrowed concepts such as "participatory sense-making", interaffordances, intercorporality, and narrative writing. In taking position as a writer and publishing research work, I contribute to value embodied knowledge, and shed light on embodied meaning in CI.

The three narratives presented here conform to Chung's (2009) definition of CI as being sometimes quiet and meditative (narratives II and I) and sometimes wild and athletic (Narrative III). My intention was to present a narrative, reflected and analytic insight into the details of embodied memory in CI, and show how the meaning and sharing 
in and of movement unfolds. In using theoretical concepts to describe and analyse lived dance experience, I have engaged in meaning-making and articulated embodied knowledge, and clarified meaning inherent in lived dance experience.

The author would like to thank the peer reviewers and editors for their work on this article.

\section{REFERENCES}

Allen-Collinson, J. (2012) Autoethnography: situating personal sporting narratives in socio-cultural contexts. In K. Young \& M. Atkinson (Eds.), Qualitative Research on Sport and Physical Culture: Research in the Sociology of Sport, volume 6, 191-212. Bingley, UK: Emerald Press. https://core. ac.uk/download/pdf/9553387.pdf (Retrieved 18.09.2018)

Anderson, L. (2006). Analytic autoethnography. Journal of Contemporary Ethnography. 35(4). 373-395. Sage publications. http://journals.sagepub.com/doi/pdf/10.1177/0891241605280449 (Retrieved 26.06.2018)

Beith, D. (2018). The birth of sense: generative passivity in Merleau-Ponty's philosophy. Athens, Ohio: Ohio University Press.

Burton, T. (2011). Painful memories: chronic pain as a form of re-membering. Memory Studies, 4(1), 2332. http://journals.sagepub.com/doi/pdf/10.1177/1750698010382158 (Retrieved 01.08.2018)

Chang, H. (2008). Autoethnography as method. Walnut Creek, USA: Left Coast Press

Chung, R. (2009). Workshop announcement. https://contactquarterly.com/contact-improvisation/about/ index.php (Retrieved 16.11.2018)

Ellis, C. S. \& Bochner, A. P. (2006). Analyzing analytic autoethnography: an autopsy. Journal of Contemporary Ethnography, 35(4), 429-449. https://doi.org/10.1177/0891241606286979 (Retrieved 19.06.2018)

Ellis, C., Adams, T. E. \& Bochner, A.P. (2011). Autoethnography: an overview [40 paragraphs]. Forum Qualitative Sozialforschung / Forum: Qualitative Social Research, 12(1), 1-18. http://nbn-resolving. de/urn:nbn:de:0114-fqs1101108 (Retrieved 03.08.2018)

Fuchs, T. (2016a). Embodied knowledge - embodied memory. In S. Rinofner-Kreidl \& H.A. Wiltsche (Eds.), Analytic and continental philosophy: methods and perspectives. Proceedings of the $37^{\text {th }}$ international Wittgenstein symposium (pp. 215-229). Berlin. http://ebookcentral.proquest.com (Retrieved 20.09.2018)

Fuchs, T. (2016b). The embodied development of language. In G., Etzelmüller and C. Tewes (Eds.), Embodiment in evolution and culture (pp. 107-128). Tübingen: Mohr Siebeck

Fuchs, T. \& De Jaegher, H. (2009). Enactive intersubjectivity: participatory sense-making and mutual incorporation. Phenomenology and the Cognitive Sciences (8), 465-486. DOI 10. 1007/s11097009-9136-4

Fuchs, T. \& Koch, S.C. (2014). Embodied affectivity: on moving and being moved. Frontiers in Psychology 5, 508, 1-21.

Little, N. (2014). Restructuring the self-sensing: attention training in contact improvisation. Journal of Dance and Somatic Practices, 6(2), 247-260.

McCormack, D. P. (2013). Refrains for moving bodies: experience and experiment in affective spaces. Durham: Duke University Press.

Merleau-Ponty, M. (2007/1945). Phenomenology of perception. London: Routledge. 
Ritchie, A. \& Brooker, F. (2018). Imaging the future: an autoethnographic journey of using a guided and cognitive-specific imagery intervention in undergraduate release-based contemporary dance technique, Research in Dance Education, 1-16. https://doi.org/10.1080/14647893.2018.1467397 (Retrieved 20.06.2018)

Rustad, H. (2006). Kroppssubjekt i dans og kontekst; en undersøkelse av mening $i$ kontaktimprovisasjon /Body-subject in dance and context; researching meaning in contact improvisation. (Master thesis). Trondheim: NTNU Norwegian University of Science and Technology.

Rustad, H. (2017). Age and gender in the European Contact improvisation community. Nordic Journal of Dance, 8(2), 71-81.

Sarah (2004). Sarah again. In P. Aerni \& M. Manning (Eds.) Underscore practice; Vellexon 2004 (pp. 36-37). Private publishing.

Stuart, S. A. J. (2012). Enkinaesthesia: The essential sensuous background for co-agency. In Z. Radman (Ed.), Knowing without thinking; Mind, Action, Cognition, and the Phenomenon of the Background (pp. 167-186). London: Palgrave Macmillan.

van Katwyk, T. \& Seko, Y. (2017). Knowing through improvisational dance: a collaborative Autoethnography. Forum Qualitative Sozialforschung / Forum: Qualitative Social Research, [S.I.], 18(2), 1-16. http://www.qualitative-research.net/index.php/fqs/article/view/2724/4087 (Retrieved 01.08.2018)

van Manen, M. (1990). Researching lived experience: human science for an action sensitive pedagogy. Albany, New York: State University of New York Press.

van Manen, M. (2014). Phenomenology of practice; meaning-giving methods in phenomenological research and writing. Walnut Creek, California: Left Coast Press.

Yohalem, H. (2018). Displacing vision: contact improvisation, anarchy, and empathy. Dance Research Journal, 50(2), 45-61. 


\section{AUTHOR BIO}

Hilde Rustad is currently employed as post-doctoral research fellow at The Norwegian school for sport sciences. Rustad has a Nordic master of arts in dance studies from the Norwegian university of science and technology. She is educated dancer and choreographer at the Amsterdam School of the Arts, School for new dance development. She is a board-member of the Nordic Forum for Dance Research, NOFOD.

bilde.rustad@nib.no

\section{FORFATTERBIOGRAFI}

Hilde Rustad er danseforsker, dansekunstner og pedagog, og ansatt som postdoktor ved Norges Idrettshøgskole. Rustad har en Nordisk Master i dansevitenskap (NO-MA-DS) fra NTNU. Hun er utdannet danser og koreograf fra Kunsthøgskolen i Amsterdam, avdeling School for New Dance Development (SNDO). Rustad er styremedlem i Nordisk Forum for Danseforskning (NOFOD).

bilde.rustad@nih.no

\section{ACKNOWLEDGEMENTS}

The author would like to thank the peer reviewers and editors for their work on this article. 